\title{
Chemical composition of animal manure: a modelling approach
}

\author{
J. BRIL \& W. SALOMONS \\ Institute for Soil Fertility Research, P.O. Box 30003, 9750 RA Haren, Netherlands
}

Received: 16 February 1990; accepted 24 April 1990

\begin{abstract}
A chemical equilibrium program (CHARON) was used to predict the chemical composition of the liquid fraction and the mineral fraction of pig and poultry manure. The results showed that the major part of calcium and magnesium in solution is complexed by dissolved organic matter. A large part of the dissolved organic matter is complexed with ammonium and potassium ions. Calculated ion activity products showed that possible mineral phases include vaterite, whitlockite, monetite and struvite in all the samples, and potassium taranakite in the pig manure samples. A number of other minerals are either unsaturated or so strongly supersatured (e.g. apatite), that they do not control the solubility of major cations and anions. Scanning Electron Microscopy/Microprobe analysis showed the abundant presence of a magnesium phosphate, most likely the mineral struvite $\left(\mathrm{MgNH}_{4} \mathrm{PO}_{4} \cdot 6 \mathrm{H}_{2} \mathrm{O}\right)$ in one of the pig manure samples.
\end{abstract}

Keywords: animal manure, speciation, minerals, phosphate, chemical model

\section{Introduction}

Animal manure is applied to agricultural land on a very large scale in the Netherlands. This has caused a number of environmental problems as discussed elsewhere (Japenga \& Harmsen, 1990). Describing and understanding the chemical composition of manure and its various solid phases is prerequisite to understanding its environmental impact. In addition, the significance of nutrients in animal manure for plant growth is not yet completely understood. The as yet unexplained slow response of plants to phosphorus from animal manure during the first few weeks after application is just one example (Prummel \& Sissingh, 1983).

We have used the detailed chemical analysis of three manure samples (Japenga \& Harmsen, 1990) to construct a chemical model. Ion activity products (IAP) were used to determine the possible existence of mineral phases. Close agreement between an IAP value and the solubility product and correct prediction of the dissolved speciation provides strong circumstantial evidence for the occurrence of a particular mineral phase (e.g., calcium carbonate, phosphate minerals, etc.). To test these predictions we performed SEM/Microprobe analysis of the solid fraction of manure. 


\section{Materials and methods}

\section{Manure composition}

The analytical procedures, and the data which are used in this article, were described by Japenga \& Harmsen (1990). The data used in this article concern the samples PS1, PM and PS-1/18. Some characteristics of these samples are given in Table 1. Sample PS-2 is not used in this article because too many essential data were missing. The solid fraction of PS-1/18 was examined for mineral composition by Scanning Electron Microscopy (SEM)/Microprobe (Philips 535, using $15 \mathrm{kV}$ accelerating voltage). The slurry was centrifuged at high speed $(18000 \mathrm{rpm})$. The centrifuge residue was washed once with acetone, then dried at $35{ }^{\circ} \mathrm{C}$ overnight.

\section{The chemical equilibrium program}

The chemical equilibrium program, which is used in this study, solves the chemical equilibrium problem by minimizing the Gibbs free energy (GFE) of the equilibrium system while keeping the mass balance constraints. The equilibrium program was developed at the RAND corporation (Shapiro, 1964; Clasen, 1965; Shapley et al., 1968). The algorithms which are used, a first-order gradient projection method and the second-order RAND algorithm, are described by Clasen (1965) and by Smith \& Missen (1982). The version of the program used in this study was developed at the Delft Hydraulics Laboratory (de Rooij, 1988) and is an integral part of the chemical program CHARON.

\section{Formulations used in the equilibrium program}

To calculate equilibrium, a GFE parameter has to be attributed to each species of the equilibrium system. CHARON needs dimensionless GFE parameters. The standard unit of the GFE in thermodynamics is $\mathrm{kcal} \mathrm{mol}^{-1}$ (or $\mathrm{kJ} \mathrm{mol}^{-1}$ ). These values are converted to dimensionless parameters by dividing the values by the product of the gas constant $R\left(1.98717 \mathrm{cal} \mathrm{mol}^{-1} \mathrm{~K}^{-1}\right)$ and the absolute temperature at the standard state $(298.15 \mathrm{~K})$.

CHARON uses the Raoult convention for the concentration unit. This means that all concentrations are expressed as moles per total number of moles in a certain phase (the mole fraction). In chemistry, the standard state of a substance dissolved

Table 1. Relevant characteristics of the slurry samples.

\begin{tabular}{|c|c|c|c|}
\hline Sample & Type & $\begin{array}{l}\text { Age } \\
\text { (months) }\end{array}$ & Characterization \\
\hline PS-1 & pig manure & $2-4$ & low total solids, high ammonium \\
\hline PS-1/18 & pig manure & $20-22$ & same sample as PS- 1 , but stored at $4^{\circ} \mathrm{C}$ for 18 months \\
\hline PM & poultry manure & $2-4$ & high calcium carbonate content \\
\hline
\end{tabular}


Table 2. Conversion of standard GFE data to C-parameters.

\begin{tabular}{|c|c|c|c|c|c|}
\hline Phase & Species & $\begin{array}{l}\Delta G_{f}^{\circ} \\
\left(\mathrm{kcal} \mathrm{mol}^{-1}\right)\end{array}$ & $\begin{array}{l}\text { Henry } \\
\text { Raoult }\end{array}$ & $\begin{array}{l}\Delta G_{f}^{\circ} / \mathrm{RT} \\
\text { (Raoult) }\end{array}$ & $\begin{array}{l}\text { C-parameter } \\
(-)\end{array}$ \\
\hline Water & $\begin{array}{l}\mathrm{H}^{+} \\
\mathrm{OH}^{-} \\
\mathrm{H}_{2} \mathrm{O} \\
\mathrm{H}_{2} \mathrm{CO}_{3} \\
\mathrm{HCO}_{3}^{-} \\
\mathrm{CO}_{3}{ }^{-} \\
\mathrm{Ca}^{+}+ \\
\mathrm{CaOH}{ }^{+} \\
\mathrm{CaHCO}_{3}{ }^{+} \\
\mathrm{CaCO}_{3}\end{array}$ & $\begin{array}{c}0.0 \\
-37.594 \\
-56.687 \\
-148.95 \\
-140.27 \\
-126.18 \\
-132.52 \\
-171.89 \\
-274.33 \\
-263.00\end{array}$ & $\begin{array}{l}4.017 \\
4.017 \\
0.0 \\
4.017 \\
4.017 \\
4.017 \\
4.017 \\
4.017 \\
4.017 \\
4.017\end{array}$ & $\begin{array}{r}4.017 \\
-59.436 \\
-95.678 \\
-247.387 \\
-232.736 \\
-208.955 \\
-219.655 \\
-286.106 \\
-459.007 \\
-439.884\end{array}$ & $\begin{array}{c}0.0 \\
0.0 \\
-40.259 \\
-46.465 \\
-27.798 \\
0.0 \\
0.0 \\
-7.014 \\
-34.414 \\
-11.274\end{array}$ \\
\hline Calcite & $\mathrm{CaCO}_{3} \mathrm{~S}$ & -270.18 & 0.0 & -456.019 & -27.409 \\
\hline $\mathrm{CO}_{2}$ gas & $\mathrm{CO}_{2}$ & -94.26 & 0.0 & -159.095 & -13.593 \\
\hline
\end{tabular}

in water is defined for the hypothetical state of infinite dilution, and at the same time a molality of 1 (the Henry convention).

Since CHARON uses the Raoult convention, values of GFE which are tabulated for the Henry convention, have to be transformed. This is done by adding to the value of $\Delta G_{f}^{\circ} / R T$ the value of the natural logarithm of 55.51 (1 kg water is 55.51 moles water). A last transformation which is often applied to the GFE parameters for CHARON calculations is the transformation to other zero-points. In standard thermodynamics, the zero-points of the GFE are given to the elements of the periodic system. However, this choice is arbitrary, since GFE values are relative quantities. To get a more convenient set of GFE parameters, the zero-points are chosen differently, depending on the problem. The GFE parameters in CHARON are called Cparameters. As an example of the calculation of C-parameters from $\Delta G_{f}^{\circ}$ values Table 2 shows the transformations for the system $\mathrm{H}_{2} \mathrm{O}-\mathrm{CaCO}_{3}-\mathrm{CO}_{2}$ (gas). In this example the species $\mathrm{H}^{+}, \mathrm{OH}^{-}, \mathrm{Ca}^{+}+$and $\mathrm{CO}_{3}{ }^{--}$get a zero value for the $\mathrm{GFE}$ parameter ( $\Delta G_{f}^{\circ}$ data taken from Sadiq \& Lindsay, 1979).

\section{Modelling manure}

\section{Model definition}

The manure liquid is modelled according to the system definition supplied in appendix A. The C-parameter is defined to be zero for the species $\mathrm{H}^{+}, \mathrm{OH}^{-}, \mathrm{Cl}^{-}$, $\mathrm{CO}_{3}{ }^{--}, \mathrm{PO}_{4}^{---}, \mathrm{Na}^{+}, \mathrm{K}^{+}, \mathrm{NH}_{4}^{+}, \mathrm{Mg}^{++}, \mathrm{Ca}{ }^{++} . \mathrm{Mn}^{++}, \mathrm{Fe}^{++}, \mathrm{Al}^{+++}$. The organic complexing capacity is represented by the component FAAC (fatty acids). The species FAAC, which represents the 'free' complexing sites, is assigned the value zero for the C-parameter. In appendix $A$ for each species the $\Delta G_{f}^{\circ}$ and its source are provided. 
Data on a number of possibly important complexes could not be found in the literature. Especially data on major complexes of $\mathrm{NH}_{4}+$ (with $\mathrm{Cl}, \mathrm{CO}_{3}, \mathrm{HCO}_{3}$, $\mathrm{HPO}_{4}$ ) are lacking. It is important to know the values of association constants of these complexes because $\mathrm{NH}_{4}+$ is the cation at the highest concentration in manure liquid (Japenga \& Harmsen, 1990). Thus, interactions between ammonium and ligands will have a profound influence on the activity of the ligands. Therefore, we determined experimentally the association constants of ammonium acetate $\left(\mathrm{NH}_{4} \mathrm{AC}\right)$, ammonium bicarbonate $\left(\mathrm{NH}_{4} \mathrm{HCO}_{3}\right)$ and potassium chloride $(\mathrm{KCl})$ ionpairs, by measuring the conductivity of salt solutions having different concentrations. Potassium chloride was taken as a reference, since the ionpair formation constant for this salt is available from the literature. Sadiq \& Lindsay (1979) reported an association constant for this ionpair of 0.2 , after measurements of Paterson et al. (1971). Garrels \& Christ (1965) reported an association constant of 1.0. The value we found is $0.3 \pm 0.05$, which agrees quite well with the value reported by Sadiq \& Lindsay.

The constants which were determined, and the ammonium sulphate association constant (Truesdell \& Jones, 1974), were used to fit values for other ionpairs based on the known values of the equivalent potassium and hydrogenium $\left(\mathrm{H}^{+}\right)$ionpairs. It is assumed that the ammonium ion has ionic properties comparable to those of the potassium ion, but is able to interact more strongly with proton acceptors (the ammonium ion is a weak acid).

For missing potassium or sodium ionpairs, the stability constants were calculated from a regression of available data (Sadiq \& Lindsay, 1979; Turner et al., 1981; Sposito \& Mattigod, 1980) for both ions.

The organic complexation constants of the $1+$ cations are defined as equal to the carbonate stability constants. Since very few data are available on the stability of organic complexes of $1^{+}$cations, and since for $2^{+}$cations the relation

$$
\log (\mathrm{K}-\text { humic })=0.5+\log \left(\mathrm{K}-\mathrm{CO}_{3}^{--}\right)
$$

can be used (data of Mantoura et al. (1978) for the values of the humic complexes compared with carbonate complexing constants given by Turner et al., 1981), this assumption probably does not overestimate the stability of the organic complexation of the $1^{+}$cations. The values used in this study are listed in Table 3 . The stability of the $\mathrm{Al}^{+++}$-phosphate complexes were estimated using the stability of the appropriate $\mathrm{Fe}^{+++}$complexes and the difference in stability between the solids variscite and strengite.

Other stability constants, with the exception of the values for the FAACcomplexes, were mainly taken from Sadiq \& Lindsay (1979). However, if Sadiq \& Lindsay did not provide a value for a possibly important species, other literature sources were used (Turner et al., 1981; Sposito \& Mattigod, 1980).

The liquid fraction of manure contains a large amount of dissolved organic substances. These substances influence the activity of dissolved cations by forming complexes. The formation constant of such a complex is often referred to as being conditional, which means that it is only applicable to the system under consideration 
Table 3. Estimated $\Delta G_{f}^{\circ}$ values and C-parameters of $1+$ cation complexes.

\begin{tabular}{|c|c|c|c|c|c|c|}
\hline & $\mathbf{K}^{+}$ & C-K+ & $\mathrm{Na}^{+}$ & $\mathrm{C}-\mathrm{Na}^{+}$ & $\mathrm{NH}_{4}{ }^{+}$ & $\mathrm{C}-\mathrm{NH}_{4}{ }^{+}$ \\
\hline Free ion & -67.51 & 0.0 & -62.59 & 0.0 & -18.99 & 0.0 \\
\hline $\mathrm{Cl}^{-}$ & -98.17 & -2.81 & -93.14 & -2.64 & -49.66 & -2.85 \\
\hline $\mathrm{CO}_{3}^{--}$ & -194.92 & -6.09 & -190.50 & -6.94 & -147.08 & -7.22 \\
\hline $\mathrm{HCO}_{3}-$ & -207.61 & -31.52 & -203.20 & -32.39 & -159.50 & -32.22 \\
\hline FAACa & -68.74 & -6.09 & -64.32 & -6.94 & -20.89 & -7.22 \\
\hline $\mathrm{PO}_{4}^{---}$ & -315.28 & -8.39 & -310.41 & -8.47 & -267.36 & -9.50 \\
\hline $\mathrm{HPO}_{4}^{--}$ & -331.11 & -39.12 & -326.21 & -39.15 & -283.13 & -40.02 \\
\hline $\mathrm{H}_{2} \mathrm{PO}_{4}^{-}$ & -339.29 & -56.95 & -334.70 & -57.50 & -291.38 & -57.98 \\
\hline
\end{tabular}

a $\Delta G_{f}^{\circ}$ of FAAC defined as zero.

(because it depends heavily on the type and amount of organics present). Since measured stability constants of the organic complexes were not available, the stability constants were estimated.

If it is assumed that the concentration of carboxylic groups (referred to as 'fatty acids'), which is determined by titration (Japenga \& Harmsen, 1990), represents the total number of dissolved organic complexation sites, and furthermore equilibrium with calcium carbonate with a solubility product of $10^{-7.6}$ is assumed, then the stability constant of the organic complexation of the calcium ion can be calculated from the measured calcium concentration, the $\mathrm{pH}$ and the alkalinity. The result is a stability constant of $10^{2.87}$ for sample PS-1, $10^{3.05}$ for sample PM and $10^{3.38}$ for sample PS-1/8. The value of this constant seems to increase with ageing of the manure. The literature values for the conditional equilibrium constants for humic complexes of calcium are in the order of $10^{3.2}$ to $10^{4.6}$ at $\mathrm{pH}=8.0$ (Mantoura et al., 1978). The $\mathrm{pH}$ of the manure liquid is between 7.5 and 8 . The calculated values are in good agreement with these literature data.

Using $10^{3}$ as the calcium complexation constant, the stability constant of the magnesium complex can be estimated to be about $10^{2.5}$. The complex constants for the $\mathrm{Fe}^{++}$and $\mathrm{Mn}^{++}$organic complexes are both estimated to be $10^{4.5}$. The stability of the $\mathrm{Al}^{+++}$complex is estimated to be $10^{9}$, the constant of $\mathrm{Fe}^{+++} 10^{14}$.

\section{Results}

\section{Complexation of the major cations}

Tables 4 and 5 show the calculated speciation of the manure liquid phase. It shows that for instance for calcium in the sample PS-1, although the dissolved concentration is $170 \mathrm{mg} \mathrm{l}^{-1}$ (Japenga \& Harmsen, 1989), the free calcium ion only has a concentration of $10.2 \%$ of this value $\left(17.3 \mathrm{mg} \mathrm{l}^{-1}\right)$. Together with an activity coefficient of 0.25 (ionic strength is 0.45 ), this means that the activity of calcium in the manure liquid is only $2.5 \%$ of the dissolved calcium concentration.

In Table 4 the calculated percentage distribution of the cations over the different ligands in the manure liquid phase, and in Table 5 the calculated percentage distri- 


\section{J. BRIL AND W. SALOMONS}

Table 4. Percentage distribution of cations over various ligands in the manure liquid.

\begin{tabular}{llllllll}
\hline Cation & Free & \multicolumn{2}{l}{ Ligands } & & & & \\
\cline { 3 - 5 } & $\mathrm{Cl}-$ & $\mathrm{OH}^{-}$ & $\mathrm{HCO}_{3}^{-}$ & $\mathrm{CO}_{3}^{--}$ & $\mathrm{\Sigma PO}_{4}$ & FAAC
\end{tabular}

(a) Sample PS-1

$\begin{array}{lrrrrrrr}\mathrm{Ca}^{++} & 10.2 & 0.1 & - \text { a } & 9.5 & 1.1 & 0.3 & 78.8 \\ \mathrm{Mg}^{++} & 8.6 & 0.1 & - & 8.5 & 1.4 & 0.5 & 80.8 \\ \mathrm{~K}^{+} & 75.5 & 0.7 & - & 10.0 & 0.2 & 0.2 & 13.4 \\ \mathrm{Na}^{+} & 59.4 & 0.5 & - & 11.5 & 0.3 & 0.2 & 28.1 \\ \mathrm{NH}_{4}^{+} & 52.8 & 0.6 & 0.7 & 12.2 & 0.2 & 0.2 & 33.3 \\ \mathrm{Mn}^{++} & 0.2 & - & - & 39.3 & 0.4 & - & 60.1 \\ \mathrm{Fe}^{++} & 0.1 & - & - & 3.0 & 1.4 & - & 95.5 \\ \mathrm{Al}^{++}+ & - & - & 13.8 & - & 0.1 & - & 86.1\end{array}$

(b) Sample PS-1/18

$\begin{array}{lccccccr}\mathrm{Ca}^{++} & 12.2 & 0.1 & - & 15.0 & 3.3 & 0.5 & 68.9 \\ \mathrm{Mg}^{++} & 10.2 & 0.1 & - & 13.5 & 4.2 & 0.8 & 71.2 \\ \mathrm{~K}^{+} & 81.0 & 0.7 & - & 14.2 & 0.4 & 0.2 & 3.4 \\ \mathrm{Na}^{+} & 71.7 & 0.5 & - & 18.5 & 1.0 & 0.2 & 8.0 \\ \mathrm{NH}_{4}+ & 66.4 & 0.6 & 1.6 & 20.4 & 0.8 & 0.3 & 9.8 \\ \mathrm{Mn}^{++} & 0.2 & - & - & 77.9 & 1.5 & - & 20.4 \\ \mathrm{Fe}^{++} & 0.3 & - & - & 13.5 & 11.9 & 0.1 & 74.1 \\ \mathrm{Al}^{++}+ & - & - & 84.2 & - & 0.2 & - & 15.6\end{array}$

(c) Sample PM

\begin{tabular}{lccccccc}
$\mathrm{Ca}^{++}$ & 8.0 & 0.1 & - & 5.7 & 0.6 & 0.45 & 85.2 \\
$\mathrm{Mg}++$ & 6.8 & 0.1 & - & 5.0 & 0.7 & 0.7 & 86.7 \\
$\mathrm{~K}^{+}$ & 78.5 & 0.9 & - & 7.9 & 0.1 & 0.3 & 12.3 \\
$\mathrm{Na}^{+}$ & 63.3 & 0.6 & - & 9.3 & 0.2 & 0.3 & 26.3 \\
$\mathrm{NH}_{4}^{+}$ & 56.8 & 0.7 & 0.6 & 9.9 & 0.2 & 0.4 & 31.4 \\
$\mathrm{Mn}^{++}$ & 0.2 & - & - & 35.1 & 0.3 & - & 64.3 \\
$\mathrm{Fe}^{++}$ & 0.1 & - & - & 2.5 & 1.0 & - & 96.3 \\
$\mathrm{Al}++$ & - & - & 8.3 & - & 0.1 & - & 91.6 \\
\hline
\end{tabular}

a - is $<0.1 \%$ or not modelled.

bution of the anions over the different cations in the liquid phase is shown. Tables 4 and 5 show that the major part of $\mathrm{Ca}^{++}$and $\mathrm{Mg}^{++}$are complexed by the ligand FAAC, whereas the larger part of FAAC forms complexes with $\mathrm{NH}_{4}{ }^{+}$and $\mathrm{K}^{+}$. Since the activity of calcium and magnesium determines to a large extent the possible mineral phases in the manure solid, it is clear that the organic complexation of these ions is the major controlling factor in determining the composition of the inorganic solids. This complexation is influenced strongly by the concentration of ammonium and potassium.

The activity of the phosphate ion, which is also of great importance for the inorganic solid composition, is also strongly influenced by the ammonium and potassi- 
Table 5. Percentage distribution of ligands over various cations in the manure liquid.

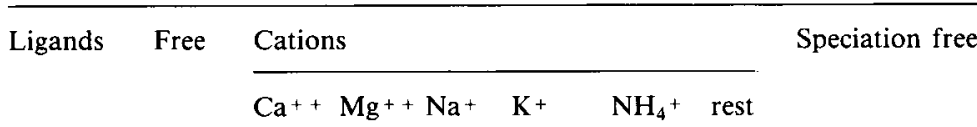

(a) Sample PS-1

$\begin{array}{lllllrrrr}\mathrm{Cl}- & 95.7 & - & - & 0.1 & 1.4 & 2.8 & - & \\ \mathrm{C}-\text { inorg } & * & 0.1 & - & 1.0 & 5.0 & 16.0 & 0.1 & * \mathrm{CO}_{2} 3.1, \mathrm{HCO}_{3}-74.3, \mathrm{CO}_{3}-0.4 \\ \text { FAAC } & 17.5 & 1.7 & 0.4 & 3.5 & 10.3 & 66.4 & 0.2 & \\ \mathrm{EPO}_{4} & * & 0.6 & 0.2 & 1.9 & 10.9 & 42.2 & - & * \mathrm{H}_{2} \mathrm{PO}_{4}-6.5, \mathrm{HPO}_{4}^{--37.7}\end{array}$

(b) Sample PS-1/18

$\begin{array}{lllllrrrr}\mathrm{Cl}^{-} & 95.2 & - & - & 0.2 & 1.4 & 3.2 & - & \\ \mathrm{C} \text {-inorg } & * & 0.1 & - & 1.1 & 5.0 & 18.5 & 0.1 & * \mathrm{CO}_{2} 1.5, \mathrm{HCO}_{3}-73.0, \mathrm{CO}_{3}^{--0} 0.7 \\ \text { FAAC } & 15.2 & 1.8 & 0.5 & 3.8 & 9.3 & 69.2 & 0.2 & \\ \mathrm{EPO}_{4} & * & 0.2 & 0.1 & 2.2 & 10.6 & 45.4 & - & * \mathrm{H}_{2} \mathrm{PO}_{4}^{-} 3.2, \mathrm{HPO}_{4}^{--38.3}\end{array}$

(c) Sample PM

\begin{tabular}{llrlrrrrr}
$\mathrm{Cl}^{-}$ & 96.2 & - & - & 0.2 & 1.9 & 1.7 & - & \\
$\mathrm{C}-$-inorg. & $*$ & 0.2 & - & 1.4 & 6.9 & 9.9 & 0.1 & $* \mathrm{CO}_{2} 4.2, \mathrm{HCO}_{3}-77.0, \mathrm{CO}_{3}^{--} 0.3$ \\
FAAC & 22.0 & 4.7 & 0.8 & 6.2 & 16.9 & 49.1 & 0.3 & \\
$\mathrm{\Sigma PO}_{4}$ & $*$ & 1.1 & 0.3 & 3.1 & 16.3 & 29.2 & - & $* \mathrm{H}_{2} \mathrm{PO}_{4}-9.3, \mathrm{HPO}_{4}^{--} 40.7$ \\
\hline
\end{tabular}

um concentration (45-55 \% of the total dissolved phosphate is bound in ammonium and potassium ionpairs).

Ion activity products for mineral phases

To evaluate the possible inorganic solids in equilibrium with manure liquid, activity product calculations can be performed for the liquid phase. Solids in equilibrium with the liquid should have an activity product close to the literature value of the solubility product.

The theoretical solubility product for the solid $A_{n} B_{m}$ is defined as:

$$
\mathrm{Ksp}=a_{\mathrm{A}}^{\mathrm{n}} \times a_{\mathrm{B}}^{\mathrm{m}}
$$

where:

$a_{\mathrm{A}}=$ the activity of the dissolved species $\mathrm{A}$

$a_{\mathrm{B}}=$ the activity of the dissolved species $\mathrm{B}$

Values of Ksp have been tabulated in the thermodynamic literature.

Mineral equilibrium data used in this study were taken from the work of Sadiq \& Lindsay (1979) (all data except vaterite, since no value is supplied for this mineral) and Plummer \& Busenberg (1982) (vaterite). 
The calculated ion activity product in the liquid fraction of manure is now defined as:

$$
\mathrm{IAP}=a_{\mathrm{A}}^{\mathrm{n}} \times a_{\mathrm{B}}^{\mathrm{m}}
$$

A measure of the degree of saturation of a solid is the value of IAP/Ksp for this solid.

Even in the presence of reactive solid phases, differences between theoretical solubility products and ion activity products can occur for a number of reasons, e.g.: 1) When solids precipitate, some degree of supersaturation occurs. Supersaturation in itself is required for nucleation of new crystals, and supersaturation will remain when precipitation is relatively fast.

2) When solids dissolve, some undersaturation is necessary to keep the dissolution going.

3) Not only the ion activity products but also the kinetics of precipitation determine to a large extent the possible solid mineral phases. Some minerals are precipitating so slowly that formation can occur only over very long periods of time. As a rule, minerals with a simple molecular structure precipitate faster than minerals with a complex molecular structure. Other ions than the constituent ions may influence the kinetics. For instance, magnesium ions may influence the precipitation kinetics of calcium phosphates; especially the precipitation of $\beta$-TCP is enhanced (Lindsay \& Vlek, 1977).

4) Theoretical solubility products are determined on pure, highly crystalline solids. In manure, the mineral phases will seldom be absolutely pure solids since various cations and anions may replace the main constituent ions (solid solution). Also, the crystallinity may vary depending on the rate of precipitation.

So there is a range of IAP values around the theoretical solubility product where neither precipitation nor dissolution occurs. However, the larger the difference between IAP and Ksp, the lower the probability of equilibrium between a certain solid phase and the liquid. Table 6 lists the results of the ion activity calculations for the liquid phase of manure.

The calculated IAP values show that possible mineral phases (with $\log (\mathrm{IAP} / \mathrm{Ksp}$ ) between -1 and +1 ), which can be in equilibrium with the samples are:

1) Calcium carbonate. The IAP of calcium carbonate is closest to the saturation of vaterite (Plummer \& Busenberg, 1982), a more soluble form than calcite. Magnesium carbonate probably does not form as a single solid, but as a solid solution in the vaterite.

2) Whitlockite ( $\beta$-tricalciumphosphate) and/or monetite $\left(\mathrm{CaHPO}_{4}\right)$.

3) Struvite. This mineral, a magnesium-ammonium-phosphate, has been identified in the solid fraction of manure samples by X-ray diffraction (Fordham \& Schwertmann, 1977). The fact that it shows a slight undersaturation is probably due to the assumptions made about the complexing capacity of the manure liquid.

4) $\mathrm{K}$-taranakite in the pig manure samples, $\mathrm{NH}_{4}$-taranakite in the poultry sample.

5) Possible other precipitates are: aluminum hydroxide (amorphous), manganese phosphate $\left(\mathrm{MnHPO}_{4}\right)$, siderite $\left(\mathrm{FeCO}_{3}\right)$. 
With respect to other minerals, the manure is either unsaturated, or so strongly supersaturated (e.g. apatite), that even if present, they do not control the solubility of the major cations and anions.

Table 6. $\Delta G_{f}^{\circ}$ of minerals and $\log (\mathrm{IAP} / \mathrm{Ksp})$ of the liquid phase of manure.

\begin{tabular}{|c|c|c|c|c|}
\hline \multirow[t]{2}{*}{ Formula and mineral name } & \multirow[t]{2}{*}{$\Delta G_{f}^{\circ}\left(\mathrm{kcal} \mathrm{mol}^{-1}\right)$} & \multicolumn{3}{|c|}{$\log (\mathrm{IAP} / \mathrm{Ksp})$} \\
\hline & & PM & PS-1 & PS- $1 / 18$ \\
\hline $\mathrm{Al}(\mathrm{OH})_{3}$ (amorphous) & -274.21 & $0.53^{*}$ & $0.56^{*}$ & 1.26 \\
\hline $\mathrm{Al}(\mathrm{OH})_{3}$ (gibbsite) & -276.43 & 2.16 & 2.19 & 2.89 \\
\hline $\mathrm{AlPO}_{4}$ (berlinite) & 388.50 & -1.53 & -1.88 & -1.73 \\
\hline $\mathrm{AlPO}_{4} \cdot 2 \mathrm{H}_{2} \mathrm{O}$ (varescite) & -505.97 & 1.46 & 1.10 & 1.26 \\
\hline \multicolumn{5}{|l|}{$\mathrm{H}_{6} \mathrm{~K}_{3} \mathrm{Al}_{5}\left(\mathrm{PO}_{4}\right)_{8} \cdot 18 \mathrm{H}_{2} \mathrm{O}$} \\
\hline (K-taranakite) & -4014.76 & 2.74 & $-0.23^{*}$ & $-0.19^{*}$ \\
\hline \multicolumn{5}{|l|}{$\mathrm{H}_{6}\left(\mathrm{NH}_{4}\right)_{3} \mathrm{Al}_{5}\left(\mathrm{PO}_{4}\right)_{8} \cdot 18 \mathrm{H}_{2} \mathrm{O}$} \\
\hline$\left(\mathrm{NH}_{4}\right.$-taranakite) & -3864.84 & $-0.65^{*}$ & -2.58 & -2.35 \\
\hline $\mathrm{CaCO}_{3}$ (aragonite) & -269.87 & $0.70^{*}$ & $0.77^{*}$ & $0.76^{*}$ \\
\hline $\mathrm{CaCO}_{3}$ (calcite) & -270.18 & $0.93^{*}$ & 1.0 & $0.99^{*}$ \\
\hline $\mathrm{CaCO}_{3}$ (vaterite) & -269.26 & $0.25^{*}$ & $0.32^{*}$ & $0.31^{*}$ \\
\hline $\mathrm{CaCO}_{3} \cdot 6 \mathrm{H}_{2} \mathrm{O}$ (ikaite) & -607.52 & -1.11 & -1.05 & -1.05 \\
\hline $\mathrm{Ca}\left(\mathrm{H}_{2} \mathrm{PO}_{4}\right)_{2} \cdot \mathrm{H}_{2} \mathrm{O}(\mathrm{MCP})$ & -734.48 & -9.92 & -10.65 & -11.60 \\
\hline $\mathrm{CaHPO}_{4} \cdot 2 \mathrm{H}_{2} \mathrm{O}$ (brushite) & -516.89 & $-0.68^{*}$ & -1.03 & -1.43 \\
\hline $\mathrm{CaHPO}_{4}$ (monetite) & -403.96 & $-0.33^{*}$ & $-0.68^{*}$ & -1.09 \\
\hline $\mathrm{Ca}_{3}\left(\mathrm{PO}_{4}\right)_{2}(\alpha-\mathrm{TCP})$ & -922.70 & -2.46 & -3.16 & -3.80 \\
\hline $\mathrm{Ca}_{3}\left(\mathrm{PO}_{4}\right)_{2}$ (whitlockite, $\beta$-TCP) & -927.37 & $0.97^{*}$ & $0.30^{*}$ & $-0.38^{*}$ \\
\hline $\mathrm{Ca}_{8} \mathrm{H}_{2}\left(\mathrm{PO}_{4}\right)_{6} \cdot 5 \mathrm{H}_{2} \mathrm{O}(\mathrm{OCP})$ & -2942.62 & -1.30 & -3.35 & -5.51 \\
\hline $\mathrm{Ca}_{10}(\mathrm{OH})_{2}\left(\mathrm{PO}_{4}\right)_{6}$ (hydroxyapatite) & -3030.24 & 15.76 & 13.77 & 11.87 \\
\hline $\mathrm{MgCO}_{3}$ (magnesite) & -245.37 & $-0.76^{*}$ & $-0.58^{*}$ & $-0.51^{*}$ \\
\hline $\mathrm{MgCO}_{3} \cdot 3 \mathrm{H}_{2} \mathrm{O}$ (nesquehonite) & -411.62 & -3.56 & -3.4 & -3.32 \\
\hline $\mathrm{MgCa}\left(\mathrm{CO}_{3}\right)_{2}$ (dolomite) & -518.25 & 2.15 & 2.4 & 2.46 \\
\hline $\mathrm{Mg}(\mathrm{OH})_{2}$ (brucite) & -199.41 & -6.36 & -6.23 & -6.01 \\
\hline $\mathrm{MgHPO}_{4} \cdot 3 \mathrm{H}_{2} \mathrm{O}$ (newberryite) & -549.04 & -2.15 & -2.40 & -2.73 \\
\hline $\mathrm{MgNH}_{4} \mathrm{PO}_{4} \cdot 6 \mathrm{H}_{2} \mathrm{O}$ (struvite) & -731.24 & $-0.76^{*}$ & $-0.69 *$ & $-0.67 *$ \\
\hline $\mathrm{MgKPO}_{4} \cdot 6 \mathrm{H}_{2} \mathrm{O}$ & -776.31 & -3.23 & -3.50 & -3.53 \\
\hline $\mathrm{Mg}_{3}\left(\mathrm{PO}_{4}\right)_{2} \cdot 8 \mathrm{H}_{2} \mathrm{O}$ (boberrite) & -1304.99 & -5.16 & -5.55 & -5.99 \\
\hline $\mathrm{Mn}(\mathrm{OH})_{2}$ (pyrochroite) & -147.76 & -8.38 & -8.22 & -7.95 \\
\hline $\mathrm{MnCO}_{3}$ (rhodochroisite) & -195.03 & -1.81 & -1.61 & -1.48 \\
\hline $\mathrm{MnHPO}_{4}$ & -334.79 & 1.32 & 1.09 & $0.82^{*}$ \\
\hline $\mathrm{Mn}_{3}\left(\mathrm{PO}_{4}\right)_{2}$ & -692.96 & -13.81 & -14.09 & -14.37 \\
\hline $\mathrm{FeCO}_{3}$ (siderite) & -161.95 & -1.01 & -1.40 & $-0.29^{*}$ \\
\hline $\mathrm{Fe}_{3}\left(\mathrm{PO}_{4}\right)_{2} \cdot 8 \mathrm{H}_{2} \mathrm{O}$ (vivianite) & -1058.36 & -3.29 & -5.34 & -2.69 \\
\hline $\mathrm{Fe}(\mathrm{OH})_{3}$ (amorphous) & -169.25 & -7.15 & -6.93 & -6.46 \\
\hline $\mathrm{FeOOH}$ (goethite) & -117.42 & -3.59 & -3.36 & -2.89 \\
\hline $\mathrm{FePO}_{4}$ & -283.19 & -9.47 & -9.63 & -9.70 \\
\hline $\mathrm{FePO}_{4} \cdot 2 \mathrm{H}_{2} \mathrm{O}$ (strengite) & -398.59 & -8.00 & -8.16 & -8.23 \\
\hline
\end{tabular}

* Possible mineral phase $(-1<\log (\mathrm{IAP} / \mathrm{Ksp})<1)$. 


\section{Solid phase analysis using Scanning Electron Microscopy}

To verify the model predictions, we performed SEM/Microprobe analysis on the solid fraction of sample PS-1/18.

Fig. 1 shows an EM picture of the solid fraction of sample PS-1/18. It was found to contain large (5-35 $\mu \mathrm{m}$ size) prismatic crystals (crystal A in Fig. 1). Upon examination of the microprobe X-ray spectrum (Fig. 2) the crystals were found to contain magnesium and phosphorus, and a small amount of potassium. Both the crystal habitus and the elemental composition strongly suggest the presence of struvite $\left(\mathrm{MgNH}_{4} \mathrm{PO}_{4} \cdot 6 \mathrm{H}_{2} \mathrm{O}\right)$. Potassium occurs through substitution for ammonium.

Some particles (size about 5-10 $\mu \mathrm{m}$ length) containing calcium and phosphorus were also found (e.g. crystal C in Fig. 1). The mineral form of this calcium phosphate could not be established. Since these particles were only detected after careful examination of the element map pictures (e.g. Fig. 10), no X-ray spectrum is available. Phosphorus was not detected in large quantities in other mineral particles.

Many flaky, possibly amorphous aggregates were detected, and found to contain

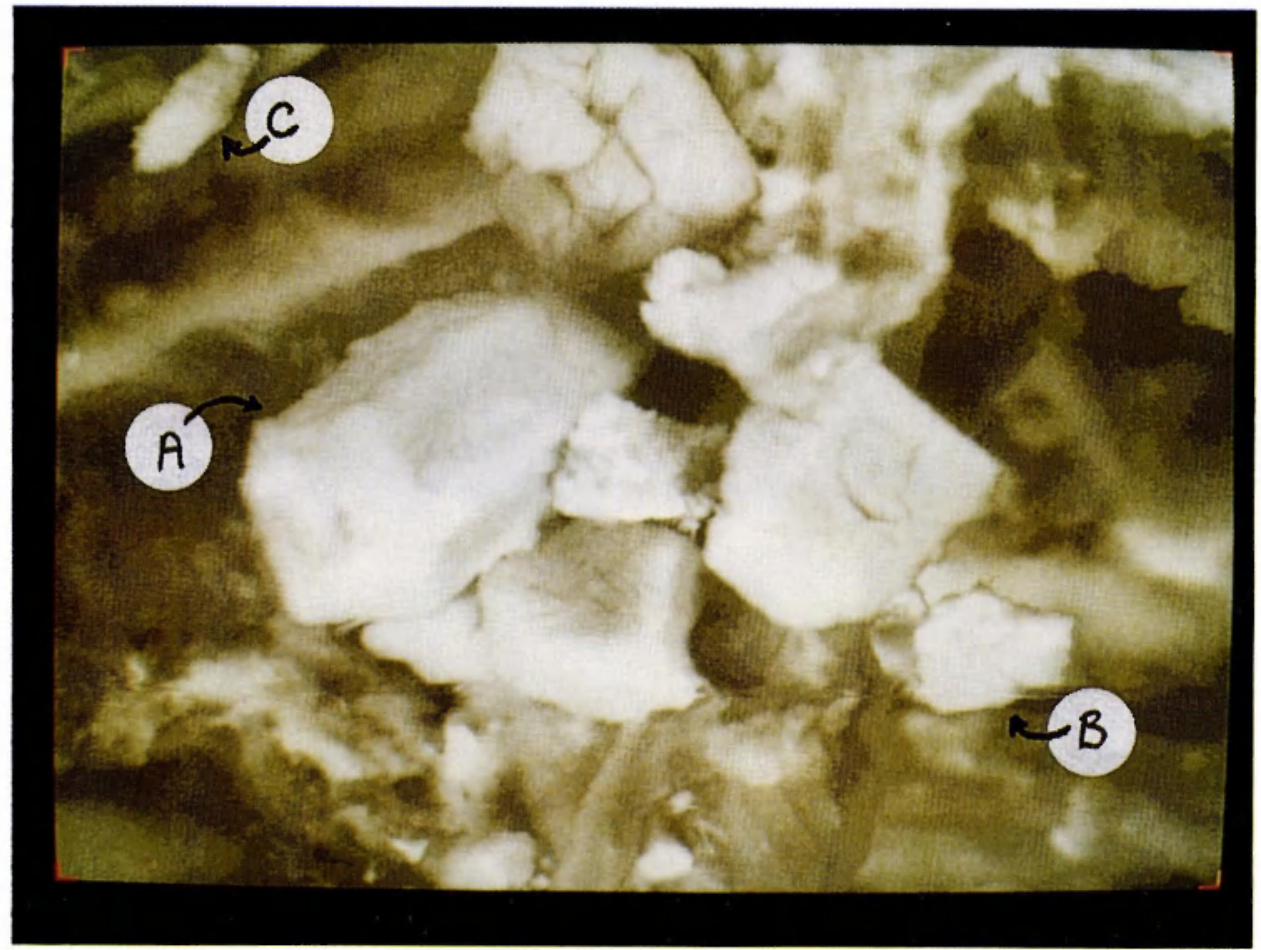

Fig. 1. EM picture of solid fraction of sample PS-1/18. A and B, respectively, denote crystals of which $\mathrm{X}$-ray spectra are shown in Figs. 3 and 4. Crystal $\mathrm{C}$ is a calcium phosphate. 
calcium and carbon (crystal B in Fig. 1, X-ray spectrum in Fig. 3), suggesting that the aggregates are some form of calcium carbonate $\left(\mathrm{CaCO}_{3}\right.$, vaterite?). The microprobe X-ray spectrum of this mineral shows a low magnesium concentration, indicating little coprecipitation of magnesium with calcium. Other particles had high concentrations of aluminum and silicon, but no elevated phosphorus content. Thus

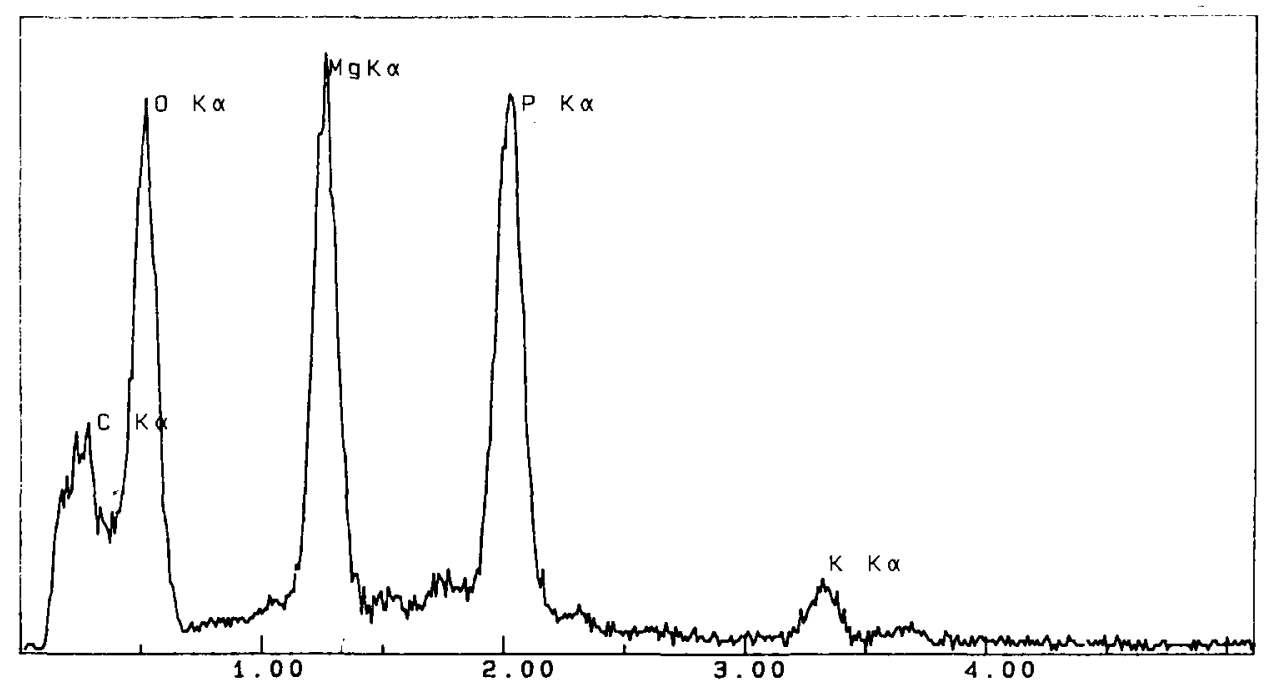

Fig. 2. X-ray spectrum of crystal A (probably struvite).

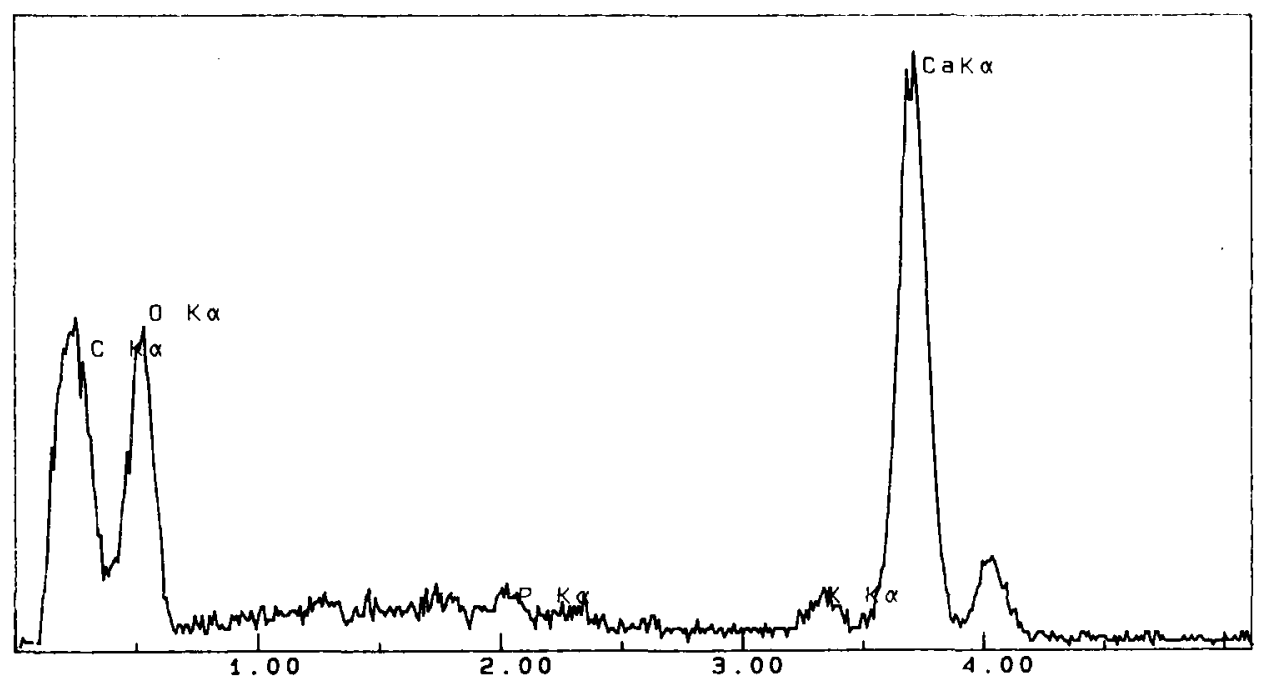

Fig. 3. X-ray spectrum of crystal B (probably vaterite). 
these particles were not taranakite but probably a clay mineral (Fig. 4). One silica crystal, probably quartz (Fig. 5), was found.

Calcium and potassium were found to be related to the organic matrix (Fig. 6). Furthermore it was found that the composition of the organic material was very variable with respect to sulfur, potassium, phosphorus and major cations (Fig. 7,

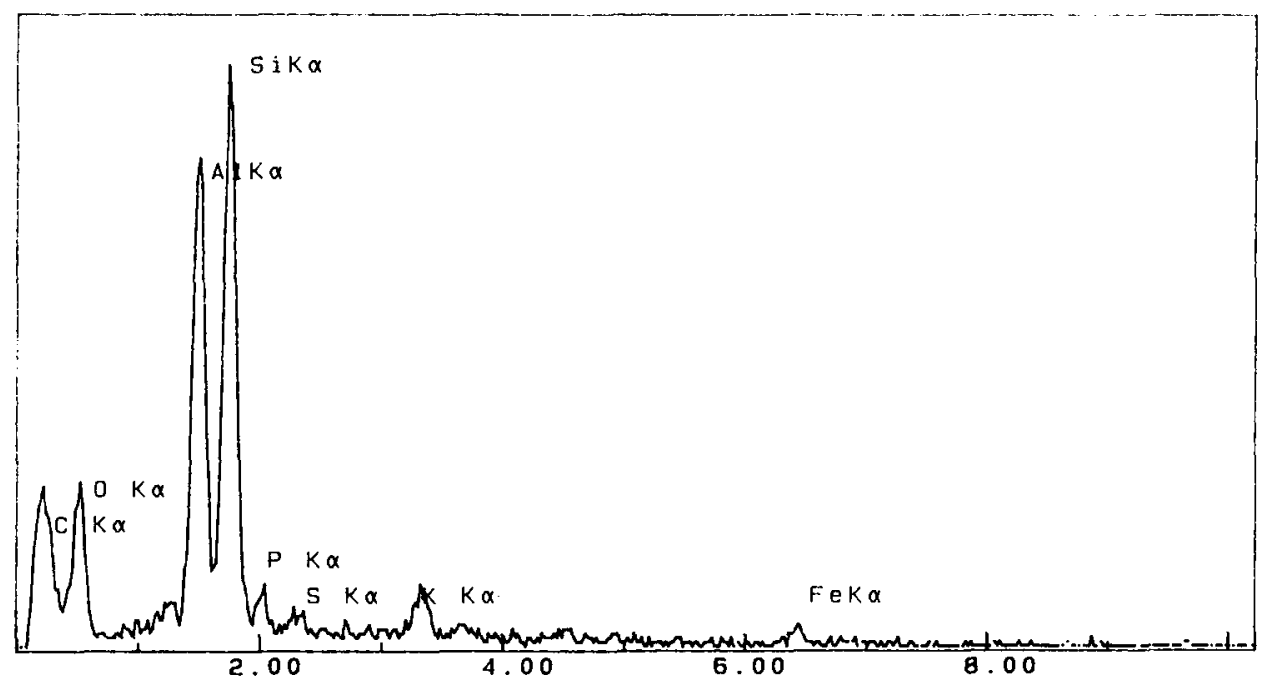

Fig. 4. X-ray spectrum of a clay mineral.

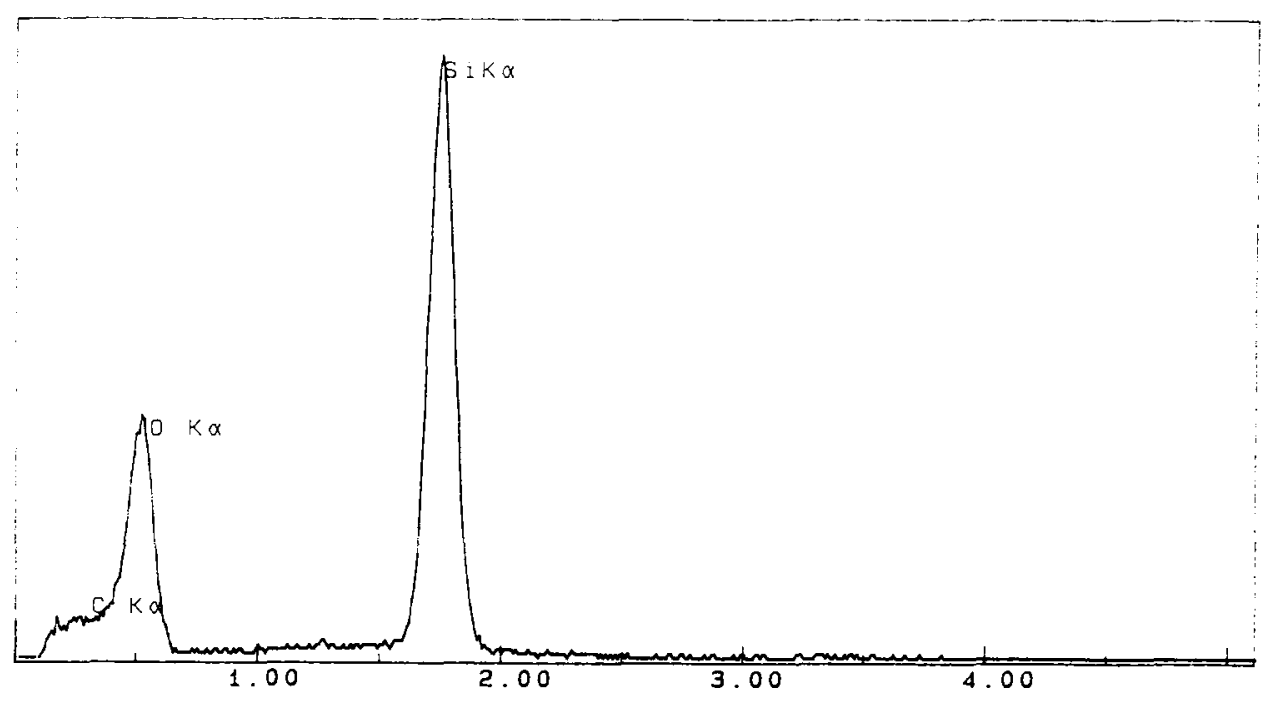

Fig. 5. X-ray spectrum of silica crystal (probably quartz). 
compare Fig. 6).

X-ray element maps (Figs. $8(\mathrm{P}), 9(\mathrm{Mg}), 10(\mathrm{Ca}$ and $\mathrm{P})$ and $11(\mathrm{Ca}$ and $\mathrm{Mg})$ ) show that the major part of the phosphorus and magnesium is bound within the magnesium phosphate crystals (struvite), making this by far the most abundant mineral phase in the solid fraction of the manure.

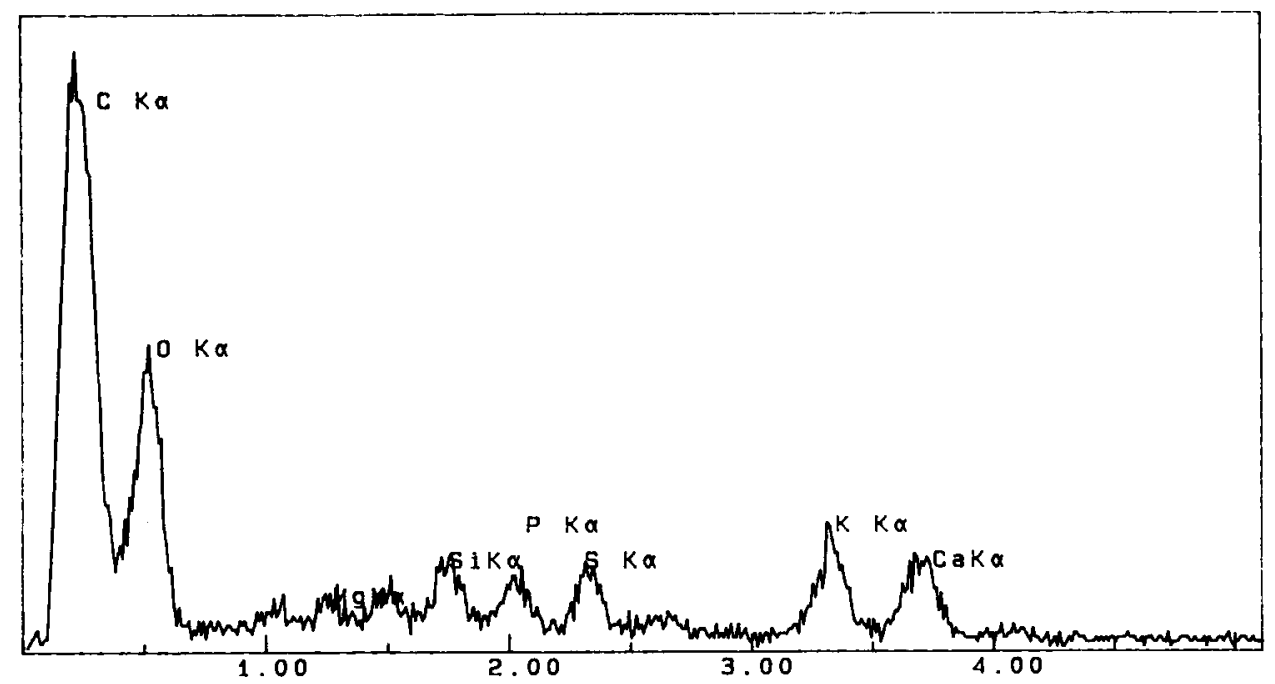

Fig. 6. X-ray spectrum of organic matter.

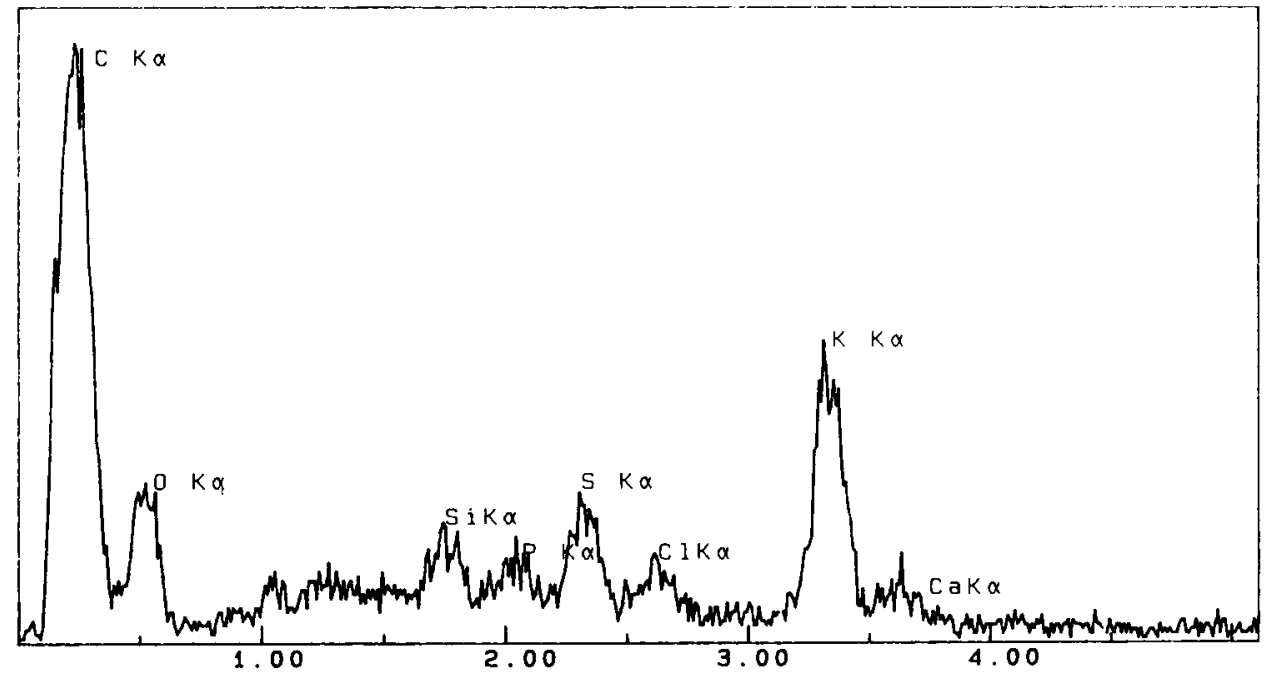

Fig. 7. X-ray spectrum of organic matter. Note the difference in composition from spectrum in Fig. 6. 


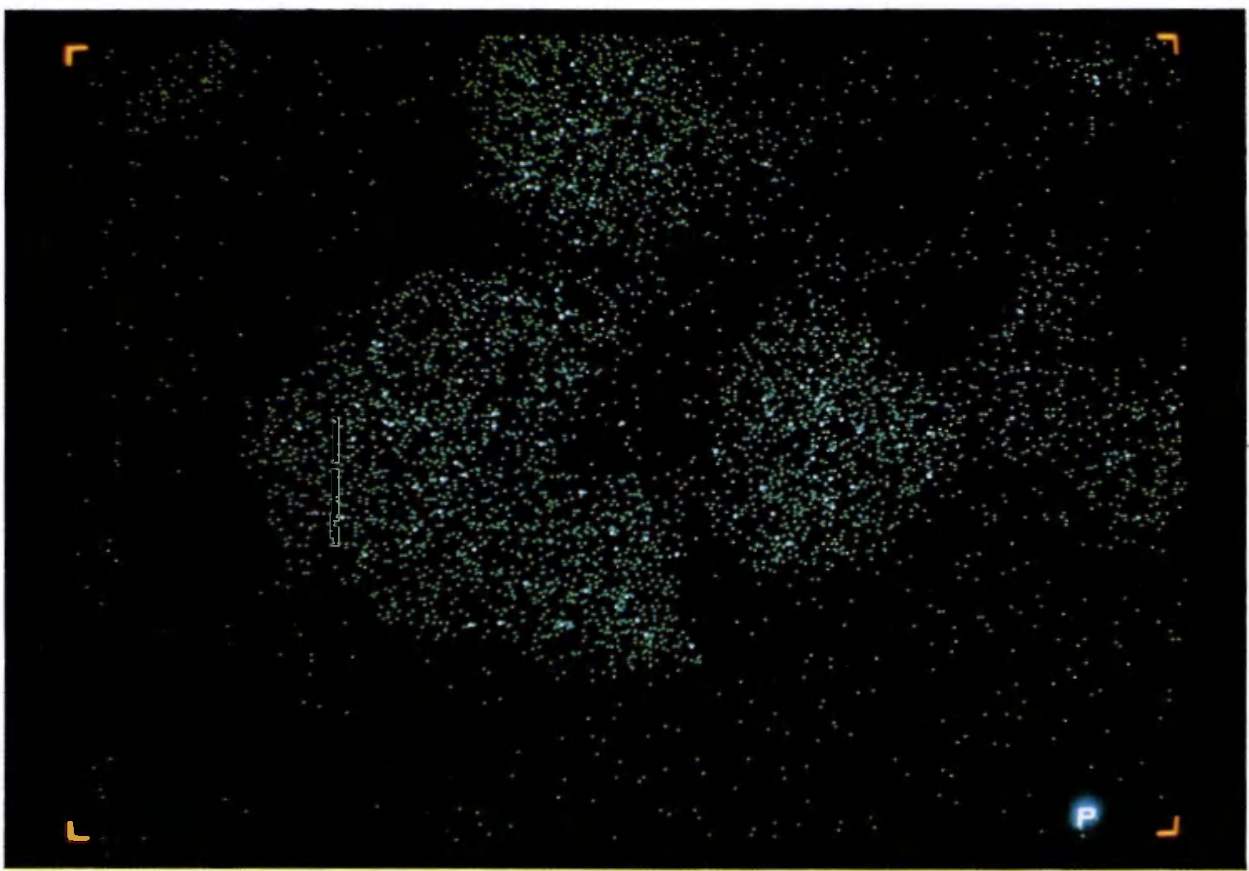

Fig. 8. X-ray element map of phosphorus from the same area as shown in Fig. 2.

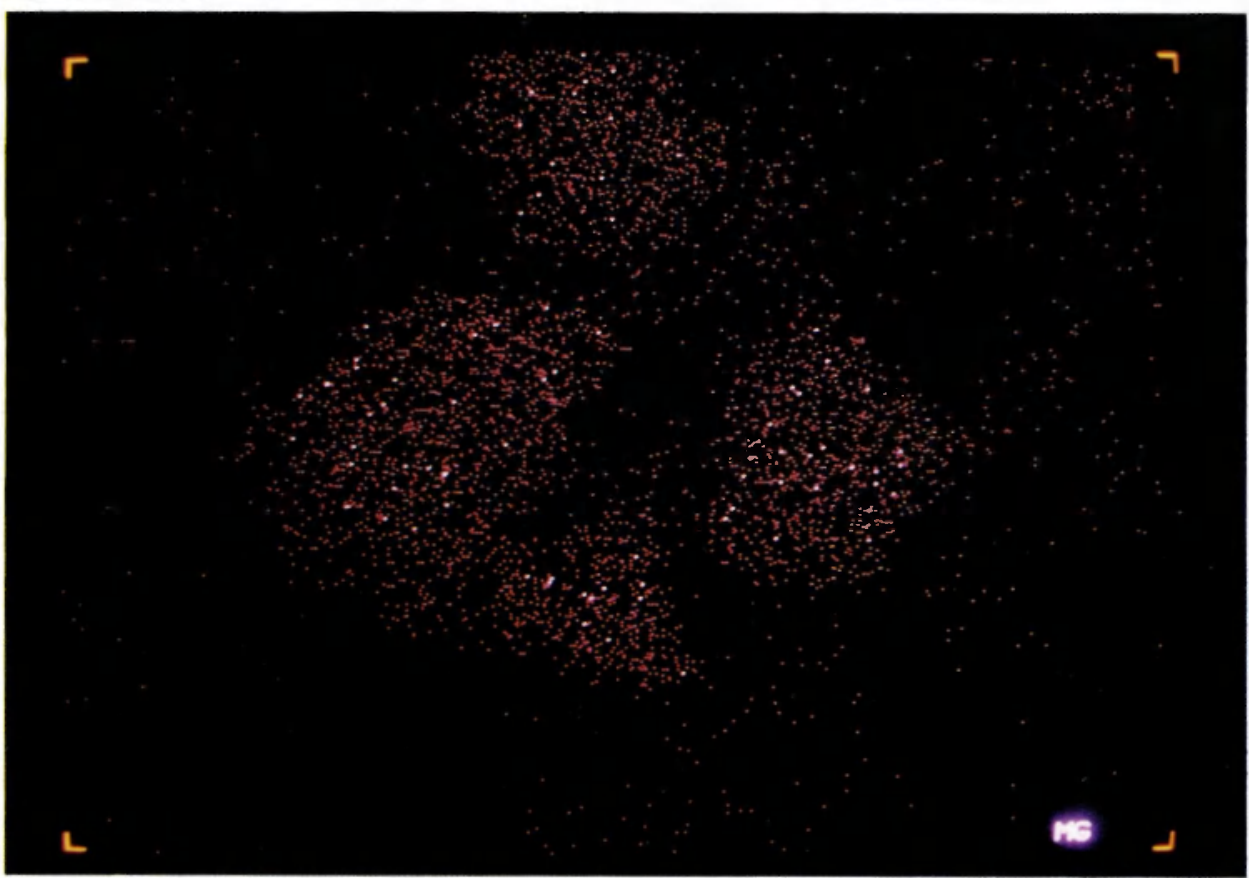

Fig. 9. X-ray element map of magnesium from the same area as shown in Fig. 2. 


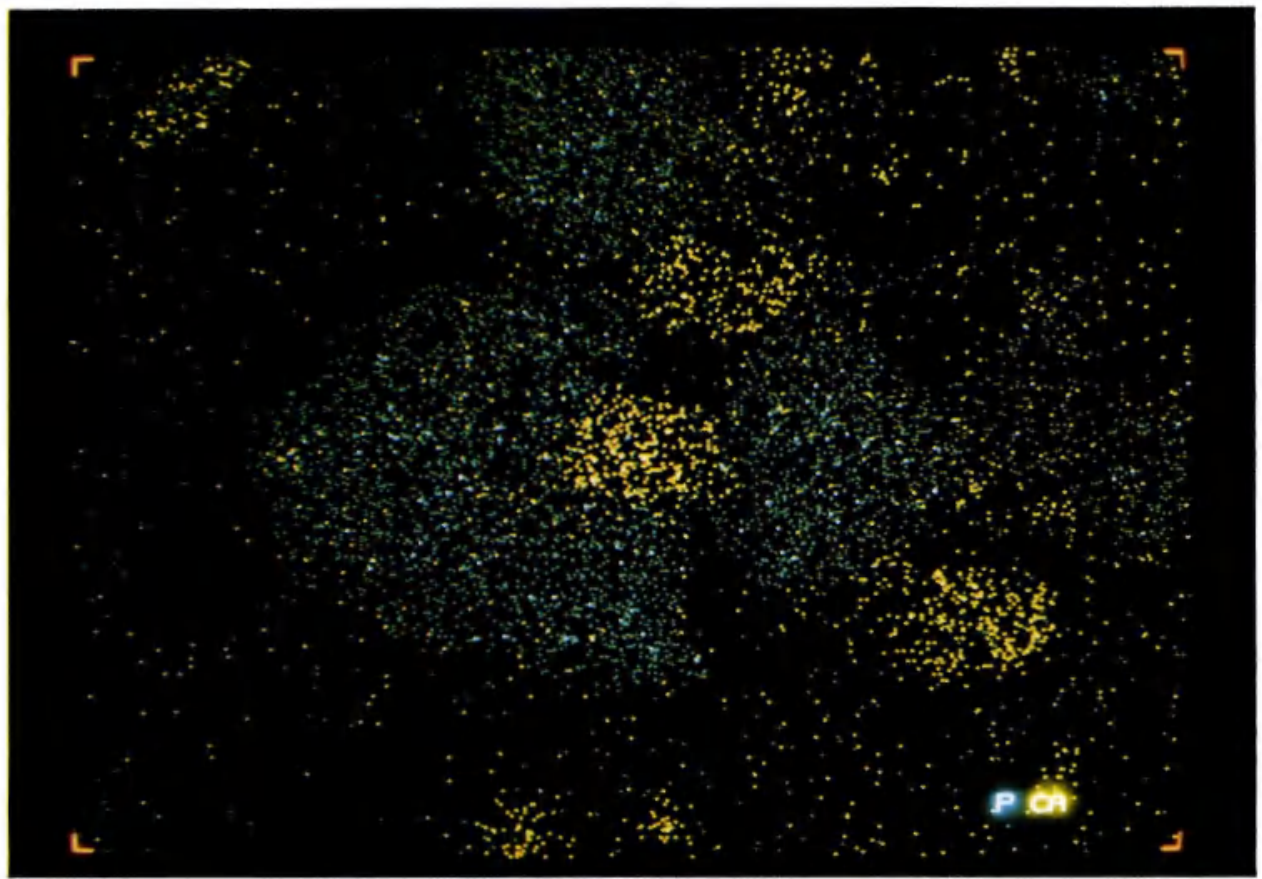

Fig. 10. X-ray element map of calcium (yellow) and phosphorus (green) from the same area as shown in Fig. 2.

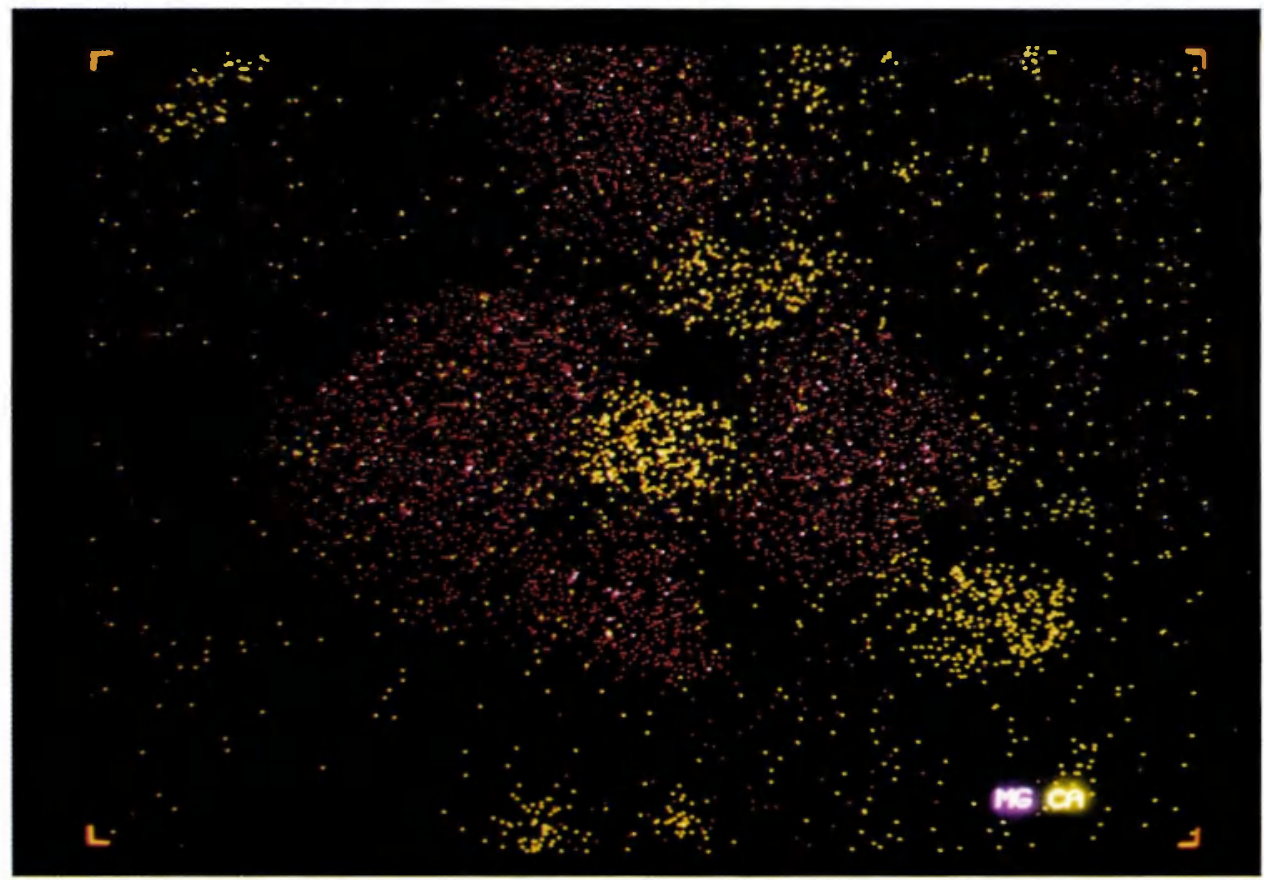

Fig. 11. X-ray element map of calcium (yellow) and magnesium (red) from the same area as shown in Fig. 2. 


\section{J. BRIL AND W. SALOMONS}

\section{Discussion}

The results of the chemical model calculations and the SEM/Microprobe analysis both show the importance of the mineral struvite in determining the phosphate concentration in the manure liquid phase. One of the reasons for the slow response of plants to animal manure phosphate is probably the slow dissolution of this mineral. This, however, has to be verified by experiments. The calculations show the importance of the dissolved organic substances in the manure liquid. Too little information is presently available on complexation capacity and strength of these substances. These substances probably also play a major role in the initial stages of the interaction of animal manure with the soil system. To understand this interaction, more study is necessary.

The model which is described in this article can be used to study the interactions between manure and soil. The model can also be used to study the effects of acidification of animal manure (a treatment proposed in the Netherlands to reduce volatilization of ammonia) on the composition of the manure.

\section{Acknowledgement}

The authors thank Anke Clerkx of TFDL (Technische en Fysische Dienst voor de Landbouw) for her cooperation in the SEM/Microprobe analysis.

\section{References}

Clasen, R. J., 1965. The numerical solution to the chemical equilibrium problem, report RM-4345-PR. RAND Corporation, Santa Monica (CA), $138 \mathrm{pp}$.

Fordham, A. W. \& U. Schwertmann, 1977. Composition and reactions of liquid manure (Gülle), with particular reference to phosphate: II. Solid phase components. Journal of Environmental Quality 6: 136-140.

Garrels, R. M., \& C. L. Christ, 1965. Solutions, minerals and equilibria. Harper and Row, New York, $420 \mathrm{pp}$.

Japenga, J. J. \& K. Harmsen, 1990. Determination of mass balances and ionic balances in animal manure. Netherlands Journal of Agricultural Science 38: 353-367.

Lindsay, W. L. \& P. L. G. Vlek, 1977. Phosphate minerals. In: J. B. Dixon \& S. B. Weed (Eds), Minerals in soil environments, p. 639-672. Soil Science Society of America, Madison, Wisconsin, USA.

Mantoura, R. F. C., A. Dickson \& J. P. Riley, 1978. The complexation of metals with humic materials in natural waters. Estuarine and Coastal Marine Science 6: 387-408.

Paterson, R., S. K. Jalota \& H. S. Dunsmore, 1971. Ion association of potassium chloride solution and its effect upon the interionic frictional coefficients of an irreversible thermodynamic analysis. Journal of the Chemical Society, Section A: 2116-2121.

Plummer, L. N. \& E. Busenberg, 1982. The solubilities of calcite, aragonite and vaterite in $\mathrm{CO}_{2}-\mathrm{H}_{2} \mathrm{O}$ solutions between 0 and $90{ }^{\circ} \mathrm{C}$, and an evaluation of the aqueous model for the system $\mathrm{CaCO}_{3}-\mathrm{CO}_{2}-$ $\mathrm{H}_{2} \mathrm{O}$. Geochimica et Cosmochimica Acta 46: 1011-1040.

Prummel, J. \& H. A. Sissingh, 1983. Phosphate effect of animal manure. (In Dutch). Bedrijfsontwikkeling 14: 963-966.

Rooij, N. M. de, 1988. Mathematical simulation of bio-chemical processes in natural waters by the model CHARON. Report on investigations, T68. Delft Hydraulics Laboratory, Delft, 436 pp.

Sadiq, M. \& W. L. Lindsay, 1979. Selection of standard Free Energies of Formation for use in soil chemistry. Technical Bulletin 134, Colorado State University, Department of Agronomy, Experiment Station, 1069 pp. 
Shapiro, N. Z., 1964. On the behavior of a chemical equilibrium system when its Free Energy Parameters are changed, report RM-4128-PR. RAND Corporation, Santa Monica (CA).

Shapley, M., L. Cutler, J. DeHaven \& N. Z. Shapiro, 1968. Specifications for a new Jacobian Package for the RAND chemical equilibrium program. Memo RM-5426-PR. RAND Corporation, Santa Monica (CA).

Smith, W. L. \& R. W. Missen, 1982. Chemical/reaction equilibrium analysis: theory and algorithms. John Wiley \& Sons, New York, $364 \mathrm{pp}$.

Sposito, G. \& S. V. Mattigod, 1980. GEOCHEM: A computer program for the calculation of chemical equilibria in soil solutions and other natural water systems. University of California, Department of Soil and Environmental Sciences, Riverside (CA).

Truesdell, A. H. \& B. F. Jones, 1974. WATEQ, a computer program for calculating chemical equilibria of natural waters. Journal of Research of the US Geological Survey 2: 233-248.

Turner, D. R., M. Whitfield \& A. G. Dickson, 1981. The equilibrium speciation of dissolved components in fresh water and seawater at $25^{\circ} \mathrm{C}$ and $1 \mathrm{~atm}$. Geochimica et Cosmochimica Acta 46: 855-882.

\section{Appendix A}

System definition manure liquid phase as used as input for CHARON.

\begin{tabular}{|c|c|c|c|c|c|c|c|}
\hline $\begin{array}{l}\text { Species } \\
\text { name }\end{array}$ & $\begin{array}{l}\Delta G_{f}^{\circ} \\
\left(\mathrm{kcal}^{-1}\right. \\
\left.\mathrm{mol}^{-1}\right)\end{array}$ & Ref. & $\begin{array}{l}\text { C- } \\
\text { param. }\end{array}$ & Stoichiome & ry (component & & \\
\hline $\mathrm{H}^{+}$ & 0.0 & 1 & 0.0 & $1 \mathrm{H}^{+}$ & & & \\
\hline $\mathrm{OH}^{-}$ & -37.59 & 1 & 0.0 & $1 \mathrm{OH}^{-}$ & & & \\
\hline $\mathrm{H}_{2} \mathrm{O}$ & -56.69 & 1 & -40.26 & $1 \mathrm{OH}^{-}$ & $1 \mathrm{H}^{+}$ & & \\
\hline $\mathrm{O}_{2}$ & 3.9 & 1 & 137.51 & $2 \mathrm{OH}^{-}$ & $-2 \mathrm{H}^{+}$ & $-4 \mathrm{EL}-$ & \\
\hline $\mathrm{Cl}-$ & -31.37 & 1 & 0.0 & $1 \mathrm{Cl}^{-}$ & & & \\
\hline $\mathrm{CO}_{2}$ & -92.26 & 1 & -6.21 & $1 \mathrm{CO}_{2}$ & & & \\
\hline $\mathrm{HCO}_{3}^{-}$ & -140.27 & 1 & -27.80 & $1 \mathrm{CO}_{2}$ & $1 \mathrm{OH}^{-}$ & & \\
\hline $\mathrm{CO}_{3}^{--}$ & -126.18 & 1 & 0.0 & $1 \mathrm{CO}_{2}$ & $1 \mathrm{OH}^{-}$ & $-1 \mathbf{H}^{+}$ & \\
\hline FAAC & 0.0 & $\mathrm{D}$ & 0.0 & 1 FAAC & & & \\
\hline $\mathrm{PO}_{4}^{---}$ & -245.18 & 1 & 0.0 & $1 \mathrm{PO}_{4}^{---}$ & & & \\
\hline $\mathrm{HPO}_{4}^{--}$ & -262.03 & 1 & -32.46 & $1 \mathrm{PO}_{4}^{---}$ & $1 \mathrm{H}^{+}$ & & \\
\hline $\mathrm{H}_{2} \mathrm{PO}_{4}^{-}$ & -271.85 & 1 & -53.30 & $1 \mathrm{PO}_{4}^{---}$ & $2 \mathrm{H}^{+}$ & & \\
\hline $\mathrm{AL}^{+++}$ & -117.33 & 1 & 0.0 & $\mathrm{IAl}+++$ & & & \\
\hline $\mathrm{AlCO}_{3}$ & -255.01 & 2 & -23.43 & $\mathbf{1 ~} \mathrm{Al}^{+++}$ & $1 \mathrm{CO}_{2}$ & $1 \mathrm{OH}^{-}$ & $-1 \mathbf{H}^{+}$ \\
\hline $\mathrm{AlHCO}_{3}$ & -260.84 & 3 & -37.98 & $1 \mathrm{Al}+++$ & $1 \mathrm{CO}_{2}$ & $1 \mathrm{OH}^{-}$ & \\
\hline $\mathrm{AlPO}_{4}$ & -373.15 & $\mathbf{E}$ & -21.98 & $1 \mathrm{Al}+++$ & $1 \mathrm{PO}_{4}^{--}$ & & \\
\hline $\mathrm{AlHPO}_{4}$ & -389.14 & $\mathrm{E}$ & -52.98 & $1 \mathrm{Al}^{+++}$ & $1 \mathrm{PO}_{4}^{---}$ & $1 \mathrm{H}^{+}$ & \\
\hline $\mathrm{AlH}_{2} \mathrm{PO}$ & -393.49 & $\mathrm{E}$ & -64.59 & $1 \mathrm{Al}+++$ & $1 \mathrm{PO}_{4}^{---}$ & $2 \mathrm{H}^{+}$ & \\
\hline $\mathrm{AlOH}++$ & -167.17 & 1 & -24.69 & $1 \mathrm{Al}^{+++}$ & $1 \mathrm{OH}^{-}$ & & \\
\hline $\mathrm{AlOH}_{2}+$ & -218.02 & 1 & -51.08 & $1 \mathrm{Al}^{+++}$ & $2 \mathrm{OH}^{-}$ & & \\
\hline $\mathrm{AlOH}_{3}$ & -266.94 & 1 & -74.21 & $1 \mathrm{Al}^{+++}$ & $3 \mathrm{OH}^{-}$ & & \\
\hline $\mathrm{AlOH}_{4}^{-}$ & -312.25 & 1 & -91.25 & $1 \mathrm{Al}^{+++}$ & $4 \mathrm{OH}^{-}$ & & \\
\hline $\mathrm{AlOH}_{5}^{--}$ & -354.06 & 1 & -102.40 & $1 \mathrm{Al}^{+++}$ & $5 \mathrm{OH}^{-}$ & & \\
\hline AlFAAC & -129.61 & $\mathrm{E}$ & -24.74 & $1 \mathrm{Al}^{+++}$ & 1 FAAC & & \\
\hline $\mathrm{Ca}^{++}$ & -132.54 & 1 & 0.0 & $1 \mathrm{Ca}^{++}$ & & & \\
\hline $\mathrm{CaCO}_{3}$ & -263.00 & 1 & -11.27 & $1 \mathrm{Ca}^{++}$ & $1 \mathrm{CO}_{2}$ & $1 \mathrm{OH}^{-}$ & $-1 \mathrm{H}^{+}$ \\
\hline $\mathrm{CaHCO}_{3}$ & -274.33 & 1 & -34.42 & $1 \mathrm{Ca}^{++}$ & $1 \mathrm{CO}_{2}$ & $1 \mathrm{OH}^{-}$ & \\
\hline $\mathrm{CaOH}+$ & -171.89 & 1 & -7.01 & $1 \mathrm{Ca}^{++}$ & $1 \mathrm{OH}^{-}$ & & \\
\hline
\end{tabular}




\section{J. BRIL AND W. SALOMONS}

Appendix A continued.

\begin{tabular}{|c|c|c|c|c|c|c|c|}
\hline $\begin{array}{l}\text { Species } \\
\text { name }\end{array}$ & $\begin{array}{l}\Delta G_{f}^{\circ} \\
\text { (kcal } \\
\left.\mathrm{mol}^{-1}\right)\end{array}$ & Ref. & $\begin{array}{l}\mathrm{C} \text { - } \\
\text { param. }\end{array}$ & Stoichior & try (components) & & \\
\hline $\mathrm{CaCl}+$ & -163.10 & 3 & -2.64 & $1 \mathrm{Ca}^{++}$ & $1 \mathrm{Cl}^{-}$ & & \\
\hline $\mathrm{CaPO}_{4}^{-}$ & -386.53 & 2 & -18.89 & $1 \mathrm{Ca}^{++}$ & $1 \mathrm{PO}_{4}^{---}$ & & \\
\hline $\mathrm{CaHPO}_{4}$ & -398.29 & 1 & -42.78 & $1 \mathrm{Ca}^{++}$ & $1 \mathrm{PO}_{4}^{---}$ & $1 \mathrm{H}^{+}$ & \\
\hline $\mathrm{CaH}_{2} \mathrm{PO}$ & -406.28 & 1 & -60.56 & $1 \mathrm{Ca}^{++}$ & $1 \mathrm{PO}_{4}^{---}$ & $2 \mathrm{H}^{+}$ & \\
\hline CaFAAC & -136.63 & $\mathrm{E}$ & -10.92 & $1 \mathrm{Ca}^{++}$ & 1 FAAC & & \\
\hline $\mathrm{Mg}^{++}$ & -109.01 & 1 & 0.0 & $1 \mathrm{Mg}^{++}$ & & & \\
\hline $\mathrm{MgCl}^{+}$ & -139.70 & 3 & -2.87 & $1 \mathrm{Mg}^{++}$ & $1 \mathrm{Cl}^{-}$ & & \\
\hline $\mathrm{MgCO}_{3}$ & -239.61 & 1 & -11.48 & $1 \mathrm{Mg}^{++}$ & $1 \mathrm{CO}_{2}$ & $1 \mathrm{OH}^{-}$ & $-1 \mathrm{H}^{+}$ \\
\hline $\mathrm{MgHCO}_{3}$ & -250.74 & 1 & -34.28 & $1 \mathrm{Mg}^{++}$ & $1 \mathrm{CO}_{2}$ & $1 \mathrm{OH}^{-}$ & \\
\hline $\mathrm{MgPO}_{4}^{-}$ & -360.81 & 2 & -15.18 & $1 \mathrm{Mg}^{++}$ & $1 \mathrm{PO}_{4}^{---}$ & & \\
\hline $\mathrm{MgHPO}_{4}$ & -375.01 & 1 & -43.17 & $1 \mathrm{Mg}^{++}$ & $1 \mathrm{PO}_{4}^{---}$ & $1 \mathrm{H}+$ & \\
\hline $\mathrm{MgH}_{2} \mathrm{PO}$ & -382.46 & 2 & -60.01 & $1 \mathrm{Mg}^{++}$ & $1 \mathrm{PO}_{4}^{---}$ & $2 \mathrm{H}^{+}$ & \\
\hline $\mathrm{MgOH}^{+}$ & -150.08 & 1 & -9.89 & $1 \mathrm{Mg}^{++}$ & $1 \mathrm{OH}^{-}$ & & \\
\hline $\mathrm{MgFAAC}$ & -112.42 & $\mathrm{E}$ & -9.77 & $1 \mathrm{Mg}^{++}$ & 1 FAAC & & \\
\hline $\mathrm{Fe}^{++}$ & -21.80 & 1 & 0.0 & $1 \mathrm{Fe}^{++}$ & & & \\
\hline $\mathrm{FeCO}_{3}$ & -155.21 & 3 & -16.22 & $1 \mathrm{Fe}^{++}$ & $1 \mathrm{CO}_{2}$ & $1 \mathrm{OH}^{-}$ & $-1 \mathbf{H}^{+}$ \\
\hline $\mathrm{FeHCO}_{3}$ & -165.71 & 3 & -37.97 & $1 \mathrm{Fe}^{++}$ & $1 \mathrm{CO}_{2}$ & $1 \mathrm{OH}^{-}$ & \\
\hline $\mathrm{FePO}_{4}^{-}$ & -277.76 & 3 & -22.21 & $1 \mathrm{Fe}^{++}$ & $1 \mathrm{PO}_{4}^{---}$ & & \\
\hline $\mathrm{FeHPO}_{4}$ & -288.74 & 1 & -44.76 & $1 \mathrm{Fe}^{++}$ & $1 \mathrm{PO}_{4}^{---}$ & $1 \mathrm{H}^{+}$ & \\
\hline $\mathrm{FeH}_{2} \mathrm{PO}$ & -297.33 & 1 & -63.28 & $1 \mathrm{Fe}^{++}$ & $1 \mathrm{PO}_{4}^{---}$ & $2 \mathrm{H}^{+}$ & \\
\hline $\mathrm{FeOH}+$ & -69.29 & 1 & -14.79 & $1 \mathrm{Fe}^{++}$ & $1 \mathrm{OH}-$ & & \\
\hline $\mathrm{FeOH}_{2}$ & -113.29 & 1 & -35.55 & $1 \mathrm{Fe}^{++}$ & $2 \mathrm{OH}^{-}$ & & \\
\hline $\mathrm{FeOH}_{3}^{-}$ & -148.22 & 1 & -37.99 & $1 \mathrm{Fe}^{++}$ & $3 \mathrm{OH}^{-}$ & & \\
\hline $\mathrm{FeOH}_{4}^{-}$ & -185.27 & 1 & -39.06 & $1 \mathrm{Fe}^{++}$ & $4 \mathrm{OH}^{-}$ & & \\
\hline FeFAAC & -27.94 & E & -14.38 & $1 \mathrm{Fe}^{++}$ & 1 FAAC & & \\
\hline $\mathrm{Fe}^{+++}$ & -4.02 & 1 & 29.96 & $1 \mathrm{Fe}^{++}$ & $-1 \mathrm{EL}-$ & & \\
\hline $\mathrm{FeCl}++$ & -37.41 & 1 & 22.54 & $1 \mathrm{Fe}^{++}$ & $-1 \mathrm{EL}^{-}$ & $1 \mathrm{CL}^{-}$ & \\
\hline $\mathrm{FeCl}_{2}+$ & -69.67 & 1 & 17.02 & $1 \mathrm{Fe}^{++}$ & $-1 \mathrm{EL}^{-}$ & $2 \mathrm{CL}^{-}$ & \\
\hline $\mathrm{FeCO}_{3}+$ & -147.80 & 3 & -3.76 & $1 \mathrm{Fe}^{++}$ & $-1 \mathrm{EL}^{-}$ & $1 \mathrm{CO}_{2}$ & $1 \mathrm{OH}^{-}-1 \mathrm{H}^{+}$ \\
\hline $\mathrm{FeHCO}$ & -150.66 & 3 & -12.61 & $1 \mathrm{Fe}^{++}$ & $-1 \mathrm{EL}^{-}$ & $1 \mathrm{CO}_{2}$ & $1 \mathrm{OH}^{-}$ \\
\hline $\mathrm{FePO}_{4}$ & -265.84 & 3 & -2.15 & $1 \mathrm{Fe}^{++}$ & $-1 \mathrm{EL}^{-}$ & $1 \mathrm{PO}_{4}^{---}$ & \\
\hline $\mathrm{FeHPO}_{4}$ & -280.93 & 1 & -29.42 & $1 \mathrm{Fe}^{++}$ & $-1 \mathrm{EL}^{-}$ & $1 \mathrm{PO}_{4}^{---}$ & $1 \mathrm{H}^{+}$ \\
\hline $\mathrm{FeH}_{2} \mathrm{PO}_{4}$ & -283.28 & 1 & -39.61 & $1 \mathrm{Fe}^{++}$ & $-1 \mathrm{EL}^{-}$ & $1 \mathrm{PO}_{4}^{-\cdots}$ & $2 \mathrm{H}^{+}$ \\
\hline $\mathrm{FeOH}^{++}$ & -57.72 & 1 & -0.62 & $1 \mathrm{Fe}^{++}$ & $-1 \mathrm{EL}^{-}$ & $1 \mathrm{OH}^{-}$ & \\
\hline $\mathrm{FeOH}_{2}{ }^{+}$ & -109.63 & 1 & -26.04 & $1 \mathrm{Fe}^{++}$ & $-1 \mathrm{EL}^{-}$ & $2 \mathrm{OH}^{-}$ & \\
\hline $\mathrm{FeOH}_{3}$ & -156.22 & 1 & -51.14 & $1 \mathrm{Fe}^{++}$ & $-1 \mathrm{EL}^{-}$ & $3 \mathrm{OH}^{-}$ & \\
\hline $\mathrm{FeOH}_{4}$ & -201.32 & 1 & -64.63 & $1 \mathrm{Fe}^{++}$ & $-1 E L-$ & $4 \mathrm{OH}^{-}$ & \\
\hline $\mathrm{Fe}_{3} \mathrm{FAA}$ & -23.12 & $\mathrm{E}$ & -6.30 & $1 \mathrm{Fe}^{++}$ & $-1 \mathrm{EL}-$ & 1 FAAC & \\
\hline $\mathrm{Mn}^{++}$ & -55.11 & 1 & 0.0 & $1 \mathrm{Mn}^{++}$ & & & \\
\hline $\mathrm{MnCl}+$ & -87.31 & 1 & -5.41 & $1 \mathrm{Mn}^{++}$ & $1 \mathrm{CL}^{-}$ & & \\
\hline $\mathrm{MnCl}_{2}$ & -117.91 & 1 & -8.13 & $1 \mathrm{Mn}^{++}$ & $2 \mathrm{CL}-$ & & \\
\hline $\mathrm{MnCO}_{3}$ & -187.43 & 3 & -14.38 & $1 \mathrm{Mn}^{++}$ & $1 \mathrm{CO}_{2}$ & $1 \mathrm{OH}^{-}$ & $-1 \mathrm{H}^{+}$ \\
\hline $\mathrm{MnHCO}_{3}$ & -197.84 & 1 & -39.98 & $1 \mathrm{Mn}^{++}$ & $1 \mathrm{CO}_{2}$ & $1 \mathrm{OH}^{-}$ & \\
\hline $\mathrm{MnOH}^{+}$ & -97.35 & 1 & -11.03 & $1 \mathrm{Mn}^{++}$ & $1 \mathrm{OH}^{-}$ & & \\
\hline $\mathrm{MnOH}_{2}$ & -138.21 & 2 & -21.39 & $1 \mathrm{Mn}^{++}$ & $2 \mathrm{OH}^{-}$ & & \\
\hline $\mathrm{MnOH}_{3}-$ & -178.80 & 1 & -29.97 & $1 \mathrm{Mn}^{++}$ & $3 \mathrm{OH}^{-}$ & & \\
\hline $\mathrm{MnPO}_{4}$ & -310.11 & 3 & -20.59 & $1 \mathrm{Mn}^{++}$ & $1 \mathrm{PO}_{4}^{---}$ & & \\
\hline $\mathrm{MnHPO}_{4}$ & -321.98 & 3 & -44.64 & $1 \mathrm{Mn}^{++}$ & $1 \mathrm{PO}_{4}^{---}$ & $1 \mathrm{H}^{+}$ & \\
\hline $\mathrm{MnH}_{2} \mathrm{PO}$ & -328.80 & 3 & -60.17 & $1 \mathrm{Mn}^{++}$ & $1 \mathrm{PO}_{4}^{---}$ & $2 \mathrm{H}^{+}$ & \\
\hline
\end{tabular}


Appendix A continued.

\begin{tabular}{|c|c|c|c|c|c|c|c|}
\hline $\begin{array}{l}\text { Species } \\
\text { name }\end{array}$ & $\begin{array}{l}\Delta G_{f}^{\circ} \\
\left(\mathrm{kcal}^{\mathrm{mol}-1}\right)\end{array}$ & Ref. & $\begin{array}{l}\text { C- } \\
\text { param. }\end{array}$ & Stoichion & try (components) & & \\
\hline MnFAAC & -61.25 & $\mathrm{E}$ & -14.38 & $1 \mathrm{Mn}^{++}$ & 1 FAAC & & \\
\hline $\mathrm{Na}^{+}$ & -62.59 & 1 & 0.0 & $1 \mathrm{Na}^{+}$ & & & \\
\hline $\mathrm{NaCl}$ & -93.14 & $\mathrm{E}$ & -2.64 & $1 \mathrm{Na}^{+}$ & $1 \mathrm{CL}^{-}$ & & \\
\hline $\mathrm{NaCO}_{3}^{-}$ & -190.50 & 1 & -6.94 & $1 \mathrm{Na}^{+}$ & $1 \mathrm{CO}_{2}$ & $1 \mathrm{OH}^{-}$ & $-1 \mathrm{H}^{+}$ \\
\hline $\mathrm{NaHCO}_{3}$ & -203.20 & 1 & -32.39 & $1 \mathrm{Na}^{+}$ & $1 \mathrm{CO}_{2}$ & $1 \mathrm{OH}^{-}$ & \\
\hline $\mathrm{NaPO}_{4}$ & -310.41 & $\mathrm{E}$ & -8.47 & $1 \mathrm{Na}^{+}$ & $1 \mathrm{PO}_{4}^{---}$ & & \\
\hline $\mathrm{NaHPO}_{4}$ & -326.21 & 2 & -39.15 & $1 \mathrm{Na}^{+}$ & $1 \mathrm{PO}_{4}^{---}$ & $1 \mathrm{H}^{+}$ & \\
\hline $\mathrm{NaH}_{2} \mathrm{PO}$ & -334.70 & $\mathrm{E}$ & -57.50 & $1 \mathrm{Na}^{+}$ & $1 \mathrm{PO}_{4}^{---}$ & $2 \mathrm{H}^{+}$ & \\
\hline NaFAAC & -64.32 & $\mathrm{E}$ & -6.94 & $1 \mathrm{Na}^{+}$ & 1 FAAC & & \\
\hline $\mathrm{K}^{+}$ & -67.51 & 1 & 0.0 & $1 \mathrm{~K}^{+}$ & & & \\
\hline $\mathrm{KCl}$ & -98.17 & $\mathrm{M}$ & -2.81 & $1 \mathrm{~K}^{+}$ & $1 \mathrm{CL}^{-}$ & & \\
\hline $\mathrm{KCO}_{3}^{-}$ & -194.92 & 3 & -6.09 & $1 \mathrm{~K}^{+}$ & $1 \mathrm{CO}_{2}$ & $1 \mathrm{OH}^{-}$ & $-1 \mathrm{H}^{+}$ \\
\hline $\mathrm{KHCO}_{3}$ & -207.61 & 3 & -31.52 & $1 \mathrm{~K}^{+}$ & $1 \mathrm{CO}_{2}$ & $1 \mathrm{OH}-$ & \\
\hline $\mathrm{KPO}_{4}^{-}$ & -315.28 & 3 & -8.39 & $1 \mathrm{~K}^{+}$ & $1 \mathrm{PO}_{4}^{---}$ & & \\
\hline $\mathrm{KHPO}_{4}-$ & -331.11 & 3 & -39.12 & $1 \mathrm{~K}^{+}$ & $1 \mathrm{PO}_{4}^{---}$ & $1 \mathrm{H}^{+}$ & \\
\hline $\mathrm{KH}_{2} \mathrm{PO}_{4}$ & -339.29 & 3 & -56.95 & $1 \mathrm{~K}^{+}$ & $1 \mathrm{PO}_{4}^{---}$ & $2 \mathrm{H}^{+}$ & \\
\hline KFAAC & -68.74 & $E$ & -6.09 & $1 \mathrm{~K}^{+}$ & 1 FAAC & & \\
\hline $\mathrm{NH}_{3}$ & -6.33 & 1 & 25.35 & $1 \mathrm{NH}_{4}^{+}$ & $-1 \mathrm{H}^{+}$ & & \\
\hline $\mathrm{NH}_{4}{ }^{+}$ & -18.99 & 1 & 0.0 & $1 \mathrm{NH}_{4}{ }^{+}$ & & & \\
\hline $\mathrm{NH}_{4} \mathrm{Cl}$ & -49.66 & $\mathrm{E}$ & -2.85 & $1 \mathrm{NH}_{4}{ }^{+}$ & $1 \mathrm{CL}^{-}$ & & \\
\hline $\mathrm{NH}_{4} \mathrm{CO}_{3}$ & -147.08 & $\mathrm{E}$ & -7.22 & $1 \mathrm{NH}_{4}{ }^{+}$ & $1 \mathrm{CO}_{2}$ & $1 \mathrm{OH}^{-}$ & $-1 \mathrm{H}^{+}$ \\
\hline $\mathrm{NH}_{5} \mathrm{CO}_{3}$ & -159.50 & $\mathrm{M}$ & -32.22 & $1 \mathrm{NH}_{4}+$ & $1 \mathrm{CO}_{2}$ & $1 \mathrm{OH}^{-}$ & \\
\hline $\mathrm{NH}_{4} \mathrm{PO}_{4}$ & -267.36 & $E$ & -9.50 & $1 \mathrm{NH}_{4}+$ & $1 \mathrm{PO}_{4}^{---}$ & & \\
\hline $\mathrm{NH}_{5} \mathrm{PO}_{4}$ & -283.13 & $\mathrm{E}$ & -40.02 & $1 \mathrm{NH}_{4}^{+}$ & $1 \mathrm{PO}_{4}^{---}$ & $1 \mathrm{H}^{+}$ & \\
\hline $\mathrm{NH}_{6} \mathrm{PO}_{4}$ & -291.28 & $\mathrm{E}$ & -57.98 & $1 \mathrm{NH}_{4}{ }^{+}$ & $1 \mathrm{PO}_{4}^{---}$ & $2 \mathrm{H}^{+}$ & \\
\hline $\mathrm{NH}_{4} \mathrm{FAA}$ & -20.89 & $\mathrm{E}$ & -7.22 & $1 \mathrm{NH}_{4}^{+}$ & $1 \mathrm{FAAC}$ & & \\
\hline
\end{tabular}

1 = Sadiq \& Lindsay, 1979; 2 = Turner et al., 1982; 3 = Sposito \& Mattigod, 1980; D = defined; $M$ $=$ measured; $E$ = estimated (see text). 